\title{
Labor market conditions and self-employment: a Denmark-Spain comparison
}

\author{
Raquel Carrasco ${ }^{1,2^{*}}$ and Mette Ejrnæs ${ }^{1,2}$
}

*Correspondence:
rcarras@eco.uc3m.es
${ }^{1}$ Universidad Carlos III de Madrid,
Leganés, Madrid, Spain
${ }^{2}$ University of Copenhagen,
Copenhagen, Denmark

Copenhagen, Denmark

\begin{abstract}
Among the OECD countries, Spain faces one of the highest rates of self-employment and Denmark one of the lowest, being the difference specially relevant among women. These two countries present important differences in their labor market conditions in terms of labor market flexibility, generosity of the unemployment benefits system, child care policies, and barriers to start and operate a business. In this paper we analyze if the different institutional environment and employment conditions in both countries can help to interpret the different incidence of self-employment rates. The study is carried out for men and women separately using a strictly comparable panel data set. The results indicate that in Spain self-employment seems to offer individuals who normally are considered as marginalized in the labor market a beneficial alternative to wage employment, while this pattern is not so clear in Denmark. Specifically, in Spain those individuals in the bottom part of the wage distribution and non-employees, particularly unemployed without unemployment benefits and mothers with small children, start more often their own business than in Denmark.
\end{abstract}

Jel codes: $\mathrm{E} 64, \mathrm{~J} 18, \mathrm{~J} 38, \mathrm{~J} 58, \mathrm{~J} 24, \mathrm{J44}, \mathrm{J} 62$

Keywords: Self-employment, Labor transitions, Employment conditions

\section{Introduction}

During the 1990s, self-employment grew faster than civilian employment as a whole in most OECD countries. ${ }^{1}$ Among self-employed, females represent one of the fastest growing segments. This increased tendency for people in industrialized countries to be self-employed has created an academic and political interest in the factors that influence individuals to become self-employed. This interest is also fuelled by the commonly held view that entrepreneurship is a source of economic growth.

Nevertheless, the incidence of self-employment is far from uniform among the OECD countries. In particular, Spain and Denmark represent countries with one of the highest and the lowest rates of self-employment. According to OECD data, by 2010 selfemployment represented $17 \%$ of total employment in Spain, while in Denmark the self-employment rate was $11.7 \%$. Furthermore, there is a considerable difference between Spain and Denmark in the fraction of female self-employment: in 2010 the fraction of women in self-employment was $12.40 \%$ in Spain and $5.50 \%$ in Denmark.

(c) 2012 Carrasco and Ejrnæs; licensee Springer. This is an Open Access article distributed under the terms of the Creative

Commons Attribution License (http://creativecommons.org/licenses/by/2.0), which permits unrestricted use, distribution, and reproduction in any medium, provided the original work is properly cited. 
In this paper we compare these two labor markets and analyze the role of the employment conditions in the decision of entering into self-employment for men and women separately. ${ }^{2}$ In particular, we exploit the differences in the labor market environment between the two countries to provide evidence about whether more obstacles for an individual to enter regular wage labor market leads her to become self-employed with a greater probability.

We make a deeper investigation of some of the issues raised by Blanchflower (2000) who analyzes the relationship between the self-employment rate and the unemployment rate for the OECD countries. We provide some further insight on certain aspects of the labor market environment such as the labor market flexibility, the generosity of the unemployment benefit system, the conditions to start and operate a business, and child care policies. This latter aspect is specially relevant for women. In the study of women's labor force participation, one of the most consistent findings is the negative effect of the presence of young children on the probability of participation. However, the simple choice between being employed and not being employed may mask important aspects of the decision regarding participation. A more enlightening approach could be to consider employment options that could lessen the constraints that child care needs place on the mother's employment. Among these employment choices, we could consider self-employment. ${ }^{3}$ Given that the institutional conditions in terms of access and cost of child care are markedly different in Denmark and Spain, we investigate the extent to which self-employment is used in both countries as a way of obtaining more flexibility in order to combine family and working life.

The dynamic aspects of self-employment are the focus of our research. ${ }^{4}$ To this end, we use six waves from a strictly comparable micro data set for Denmark and Spain, The European Community Household Panel (ECHP). These data allow us to observe transitions into self-employment, and not only the stock of self-employed individuals. As far as the empirical strategy is concerned, we offer evidence on the characteristics of the self-employed in both countries and estimate reduced form parametric transition probabilities from employment and non-employment to self-employment, for men and women separately.

Our results indicate that being disadvantaged on the labor market (measured in a number of ways) has a greater effect on the probability of becoming self-employed in Spain than in Denmark. Specifically, in Spain, individuals in the bottom part of the wage distribution start more often their own business. Moreover, the entrance form nonemployment is considerably higher for Spanish than for Danish workers, specially if they do not receive unemployment benefits and if they are mothers with small children. Finally, we do not find strong evidence that the lack of relatively cheap child care in Spain put some extra incentives on mothers with small children to start as self-employed, since we only find evidence in favor of this hypothesis for women coming from non-employment but not for those coming from wage-employment.

The paper is organized as follows. Section 2 describes the underlying theoretical framework and relationships to be studied. The relevant features of the Danish and Spanish labor markets are described in Section 3 and the data set is described in Section 4. In Section 5 we present the estimation strategy and discuss the empirical results. The final section summarizes and concludes. 


\section{Conceptual framework}

Our underlying theoretical approach is based on the comparative advantage framework used in Evans and Jovanovic (1989), Evans and Leighton (1989) and Taylor (1999), among others. The individual will switch from employment or non-employment (unemployment and out of labor force $)^{5}$ to self-employment if the expected value of self-employment exceeds the expected value of the other alternative. From previous studies we know that, in addition to personal characteristics and business cycle conditions, other factors, like barriers in the wage sector and institutional factors, contribute to explain selfemployment growth. As Blanchflower (2000) recognizes, there has been relatively little work on how institutional factors influence self-employment. ${ }^{6}$ In this paper, because of lack of regional disaggregation, these issues can be only examined indirectly by comparing the two economies. We discuss below some of the factors that affect self-employment decisions and that will be addressed in the empirical section.

\subsection{Barriers in the wage sector}

The literature on the determinants of self-employment often uses the distinction between "push" and "pull" factors, where push factors are barriers in wage-employment and pull factors are conditions making self-employment more attractive. A number of empirical studies using micro data have identified these factors. Prominent candidates among the push factors are lack of job opportunities, unemployment, and discrimination (see. e.g. Light (1980), Devine (1994), Evans and Leighton (1989), Clark and Drinkwater (2000) and Moore and Mueller (2002)). Disadvantaged groups in the wage sector may use self-employment as a source of economic advancement. Inspired by the literature, we analyze this in a number of ways. Prior labor market status and the attachment to the labor force could be proxies for opportunities in the labor market. Examining transitions into self-employment from wage employment, and unemployment and out of the labor force enables us to assess whether non-employed individuals are proner to become self-employed than wage-workers are. Previous wage is also used to analyze whether selfemployment offers better opportunities for individuals at the bottom or at the top of the wage distribution.

\subsection{Unemployment insurance system}

Concerning the factors that influence the transition from unemployment to selfemployment, one important variable is whether the unemployed worker receives unemployment benefits or not. Standard search theory predicts a disincentive effects of benefits. Since benefits are the main source of income when unemployed, when they are exhausted, search intensity rises and the reservation wage falls, so that the opportunity cost of search decreases, thereby leading to an increase in the probability of leaving unemployment. ${ }^{7}$ In this paper we focus on the effect of receiving benefits on the transition from unemployment to self-employment versus the transition to paid employment.

\subsection{Gender and flexible work schedule}

Gender differences in self-employment are also well documented in the literature. Personal characteristics such as family size, marital status, and the presence and ages of children play a different role for women than they do for men. Boden (1996) and Wellington (2006) find that women with young children or family responsibilities are 
more likely to become self-employed and Lombard (2001) and Hughes (2003) show that flexibility and work and family balance are important reasons for women for becoming self-employed. Bonet et al. (2012) find that women with a temporary contract are more likely to enter into self-employment upon motherhood than those with a permanent contract, and interpret this result as evidence that temporary contracts offer higher difficulty to balance work and family. In this paper we try to examine to what extent the possibility of better handle family responsibilities and career affects the entry into self-employment for women with children. Nonetheless, this role for female self-employment could be compensated by the existence of child care policies (see Connelly 1992). This would imply that institutions and family friendly policies are likely to intertwine in the individuals' labor market decisions. ${ }^{8}$

\subsection{Assets}

The literature has also looked at the impact of wealth and capital income on the entry into self-employment. The fact that high capital income usually increases the likelihood of becoming self-employed is taken as evidence for the existence of liquidity constraints (see e.g. Evans and Leighton (1989), Blanchflower and Oswald (1998), and Dunn and Holtz-Eakin (2000)). The underlying idea is that lack of capital should prevent some individuals from entering into self-employment. However, this is not the only explanation which is consistent with the fact that high capital income increases the likelihood of becoming self-employed. An alternative explanation is that agents are risk averse and that the income as self-employed is more uncertain. In this case, high capital income will make the risk associated with working as self-employed less important. This means that the likelihood for being self-employed could increase with a non-regular income, even in the absence of a liquidity constraint. In this paper we use household capital income to capture the effect of assets.

\section{The Danish and Spanish labor markets}

\subsection{Some institutional differences}

In this section we describe some differences between Denmark and Spain in relation to the regulation of the labor market and that are candidates to explain the differences in the evolution of the self-employment rates in both countries.

\subsubsection{Labor market flexibility}

The Danish and Spanish labor markets represent two very different labor markets. The Danish one is often characterized as an classical example of the "Flexicurity model", where there are low cost of hiring and firing but also a security system that insures individuals a fairly generous compensation when been unemployed. On the other hand, the Spanish labor market has more rigidities, with a high degree of employment protection. ${ }^{10}$ This is achieved by high firing costs, although several reforms have significantly relaxed some restrictions. The most significant change in this regard was the introduction in 1984 of new fixed-term contracts with lower dismissal costs than the permanent ones.

\subsubsection{Unemployment insurance system}

In Denmark in the 1990s, the public support incentive structure has been classified as being too generous by numerous OECD reports. ${ }^{11}$ To be entitled to unemployment 
benefit, the requirement is, besides the membership of an unemployment fund, at least six months of work within the last three years and availability to take on a job. The maximum duration of unemployment benefit was (most of the period) of five years ${ }^{12}$ with a replacement rate of $90 \%$ subject to a ceiling. In Spain the unemployment insurance system is less generous. Since 1992 the requirement is twelve months of contributions over the past six years. In 1992, the replacement ratio was reduced from $80 \%$ of the previous wage during the first six months to $70 \%$ in months $1-6$ and to $60 \%$ afterwards. It is subject to a floor of $75 \%$ of the minimum wage and to a ceiling depending on the family responsibilities. The duration of the unemployment benefit is equal to one third of tenure (from 1 year), subject to a maximum of two years. ${ }^{13}$

\subsubsection{Child care}

In terms of maternity leave policies and supply of child care there are also pronounced differences between Spain and Denmark. In Denmark in the 1990s, paid maternity leave was 6 months in connection with the birth and in the period 1994-2001 parents could take an additional 24 weeks at a lower compensation rate. ${ }^{14}$ However, these rules did not applied to self-employed women, which made it much more costly for them to go on maternity leave. For Spain the maternity leave is 16 weeks. The mother has to take at least 6 and the rest can be taken by the father. The compensation rate is equal to the $100 \%$ of the pension rights. For the self-employed, the rules are the same as for employees and the compensation is also the $100 \%$ of the pension rights which varies depending on their contributions to the Social Security.

With regards to child care usage, Denmark and Spain present very different behavior. In Denmark the child care is subsidized by the state and it is very frequently used, e.g. in $1996,50 \%$ of children aged $0-2$ and $85 \%$ of all children aged 3-5 were using a nursery school. Although this number has been steadily increasing during the last 15 years, the usage of child care has traditionally been high (in 1980 it was 50\%). In Spain the usage of child care is less common than in other European countries. A distinguishing feature that characterizes the Spanish child care policies is that most of them are programs for children aged three or over. In particular, in 1990 the government implemented a reform which led to the introduction of subsidized child care for all 3-year olds. ${ }^{15}$ In contrast, the percentage of Spanish children aged two or under cared for in public or private centers is one of the lowest in the European Union (8.7\%) in the years under study.

\subsubsection{Barriers to start and operate a business}

Denmark and Spain present differences in terms of the barriers to becoming selfemployed and running business. The Doing Business World Bank Data (2012) provides objective measures of business regulations and their enforcement across 185 economies. Each economy is ranked according to indicators measuring the procedures, time, and costs necessary to register and operate a firm. According to this ranking Denmark is in the 5th position, while Spain is in the 44th. This means that the regulatory environment is more conductive to starting and operating a business in Denmark than in Spain. Moreover, the OECD indicators of Product Market Regulation also shows a similar picture. These indicators measure the degree to which policies promote or inhibit competition. Specifically, according to there indicators such as state control, barriers to entrepreneurship, and barrier to international trade and investment, Spain is among the 
"relatively restrictive" countries, while Denmark is among the "relatively liberal" countries (see Conway et al. (2005) for details).

\subsection{Summary statistics for the labor markets}

Since early 1980s self-employment fell relative to overall employment in Denmark, while in Spain self-employment expanded faster that overall non-agricultural employment. In spite of these differences, the proportion of total self-employment in agriculture has declined dramatically in both countries between 1979 and 1995 (from 31.8\% to 21.86\% in Denmark and from $42.12 \%$ to $22 \%$ in Spain, according to OECD data). This evolution reflects the special characteristics of self-employment in agriculture, a sector in which employment in general is decreasing noticeably. To abstract from the effect of the decline in agricultural employment, we exclude this sector from our analysis.

Table 1 shows some differences in the patterns according to sex. The level of nonagricultural self-employment is much lower in Denmark for both men and women. Moreover, Spain has had an increase in self-employment for both sexes. In Denmark the proportion of self-employed women is more or less constant along the period while the proportion of men has decreased.

Concerning the unemployment rate, the Spanish labor market has displayed one of the highest unemployment rates in the OECD, with an average unemployment rate close to 20\% since the mid-1980s, while Denmark faces one of the lowest (in some industries unemployment is below 4\%). Women, both in Spain and Denmark, experience unemployment more often than men. However, Spanish women are much more exposed to unemployment than Danish women. Another characteristic of Spanish unemployment is long unemployment durations: the proportion of the unemployed who stay unemployed a year or more has followed an increasing pattern in Spain, while in Denmark the level of long-term unemployment has decreased during the 1990s.

Other feature markedly different in the two countries is the labor force participation, which is higher in Denmark for men and, in particular, for women. ${ }^{16}$ Spanish female labor force participation rates have historically been among the lowest of all OECD countries. ${ }^{17}$

Table 1 Non-agricultural self-employment in Denmark and Spain (as a proportion of total employment)

\begin{tabular}{lccccc}
\hline & \multicolumn{2}{c}{ Denmark } & & \multicolumn{2}{c}{ Spain } \\
\cline { 2 - 3 } & Men & Women & & Men & Women \\
\hline Years & 9.96 & 3.55 & 17.08 & 12.54 \\
1979 & 8.07 & 3.47 & 19.77 & 14.22 \\
1985 & 8.14 & 3.62 & 19.40 & 14.45 \\
1986 & 8.14 & 3.64 & 20.26 & 15.34 \\
1987 & 8.19 & 3.71 & 19.75 & 14.71 \\
1988 & 8.03 & 3.61 & 19.24 & 14.07 \\
1989 & 7.79 & 3.55 & 19.04 & 13.28 \\
1990 & 8.84 & 3.91 & 19.34 & 13.43 \\
1991 & - & - & 20.32 & 14.03 \\
1992 & 8.85 & 4.02 & 20.89 & 14.45 \\
1993 & 8.35 & 4.02 & 21.22 & 14.01 \\
1994 & 7.94 & 3.78 & 20.86 & 14.56 \\
1995 & & & & \\
\hline Sourcennnn
\end{tabular}

Source: OECD Labor Force Statistics (various). 
However, women participation has increased significantly during the 1970s and the 1980s, specially among younger women. On the other hand, in Spain male participation has been declining considerably since the 1970s, as in many other European countries, while in Denmark there has been a less clear decrease.

Finally, part-time employment is relatively more important in Denmark than in Spain. Part-time employment has stagnated on a high level in Denmark in the 1990s, particularly for women. ${ }^{18}$ The key issue concerning self-employment is that the high level of this form of employment could reduce the incentives to enter self-employment looking for more flexibility, while in Spain the lack of part-time jobs may push some women into selfemployment. In fact, the proportion of self-employment plus part-time employment in both countries are rather similar.

\section{Data description}

The data we use come from the European Community Household Panel (ECHP), which is a panel of households in the European Union provided by Eurostat. We use six waves covering the period 1994-1999. Every year the selected households in each country are interviewed about issues relating to demographics, labor market, income and living conditions. One of the advantages of this sample is that the same questionnaire is used in all countries, which makes the information directly comparable. A second advantage is the longitudinal aspect of the data, which allows us to observe transitions into self-employment.

Our sample includes individuals aged 20 to 59 . We select the 20-59 age band because we can find different rules of behavior in the youngest and oldest individuals, and this can distort the results. We also exclude the agricultural sector from our sample. Self-employed workers are defined as those individuals who identify themselves as self-employed as their main activity (with or without employees). Unpaid family workers are not counted as self-employed.

The explanatory variables used in the estimation can be classified into two groups: demographic variables relating to the individual, and economic variables relating to business cycle conditions. In the first group we include variables reflecting the family background and variables relating to the earnings and wealth of the individual. Business cycle effects are captured by including the unemployment rate by gender and age.

Focusing our attention on those individuals working at the time of the interview, and discarding observations with missing data for any of the relevant variables, results in a sample of 14,544 observations for the whole period considered for Denmark, of which $51.2 \%$ are males, and $48.8 \%$ are females. For men, $6.8 \%$ are self-employed and the remaining $93.2 \%$ are wage-employed. For women, $3.7 \%$ are self-employed and $96.3 \%$ are in wage-employment. For Spain, we have a sample of 31,321 observations, of which $64.4 \%$ are males and $35.6 \%$ are females. For males, $20.1 \%$ are self-employed, while for women $13.3 \%$ are self-employed. A comparison between the data and the aggregated statistics shows similar self employment rates for the different groups considered here.

The variables are defined in Table 2 and descriptive statistics are presented in Tables 3 and 4. Self-employed workers are older on average than wage-employees and are also more likely to be married. For Denmark, self-employees are more likely to be skilled, while for Spain the percentage of skilled workers in self-employment is somewhat smaller than in wage-employment. 
Table 2 Variables' definition

\begin{tabular}{|c|c|}
\hline Age & Individual's age, ranging from 20 to 59 \\
\hline Married & Equal to 1 for cohabiting individuals \\
\hline Univ. education & Equal to 1 for indiv. with university education \\
\hline Skilled & Equal to 1 for skilled individuals \\
\hline Child 0-2 & Equal to 1 for indiv. with children aged 0 to 2 \\
\hline Child 3-6 & Equal to 1 for indiv. with children aged 3 to 6 \\
\hline Child 7-16 & Equal to 1 for indiv. with children aged 7 to 16 \\
\hline Citizen & Equal to 1 for indiv. with Danish/Spanish citizenship \\
\hline Health & Self assessed health 1-5 (1 good and 5 bad) \\
\hline Relatives se & Equal to 1 if the there are any SE in the household \\
\hline Work income & Total labor income \\
\hline Capital income & Total capital income \\
\hline Benefits & Equal to 1 for indiv. receiving unempl. benefits \\
\hline NE & $\begin{array}{l}\text { Equal to } 1 \text { if the indiv. was either unemployed or out of the } \\
\text { labor force and } 0 \text { if the indiv. was wage-employed }\end{array}$ \\
\hline WE & $\begin{array}{l}\text { Equal to } 1 \text { if the indiv. was employed } \\
\text { and } 0 \text { if the indiv. was unemployed or out of the labor force }\end{array}$ \\
\hline Working hours & Number of working hours \\
\hline Job tenure & Number of years in present job, 0 if not employed \\
\hline Private sector & Equal to 1 if working in the private sector \\
\hline Hotel/Transport & Equal to 1 if working in the Hotel or Transportation sector \\
\hline Finance & Equal to 1 if working in the Finance or Business sector \\
\hline Wholesale & Equal to 1 for working in the Wholesale or Construct. sector \\
\hline Services & Equal to 1 for working in the Service sector \\
\hline Unemployment Rate & $\begin{array}{l}\text { Age (five years band) and gender specific } \\
\text { national unemployment rate (source: ILO) }\end{array}$ \\
\hline
\end{tabular}

Concerning labor market behavior, men and women tend to work more hours in selfemployment than in wage-employment in both countries. Moreover, the data suggest a link between work schedules and self-employment for mothers with small children in Spain: the average number of working hours of Spanish self-employed women is about 44 per week, whereas the corresponding figures for women without and with small children is 45 and 40 respectively. Furthermore, these differences are not observed neither for Spanish women in wage-employment nor for Danish women or men.

Regarding capital income, self-employed workers in Denmark and self-employed men in Spain have on average more capital income than employees, while for self-employed women in Spain is the opposite. Spanish men in self-employment work about $20 \%$ more than Spanish men in wage employment but earn about 15\% less.

Table 5 offers additional information about the type of individuals who become selfemployed. Looking at those individuals who are not employed in a given period and who actually find a job the subsequent year, we find that those who declare to had bad or very bad chances of getting a job in Spain are more likely to become self-employed. For Denmark the results are the opposite.

\section{Estimation results}

To model the transitions into self-employment, we use discrete choice models. Since the scope of this paper is to model the choice of occupation, rather than the decision 
Table 3 Descriptive statistics for the Danish sample

\begin{tabular}{|c|c|c|c|c|c|c|c|c|}
\hline & \multicolumn{4}{|c|}{ Men } & \multicolumn{4}{|c|}{ Women } \\
\hline & \multicolumn{2}{|c|}{ SE } & \multicolumn{2}{|c|}{ WE } & \multicolumn{2}{|c|}{ SE } & \multicolumn{2}{|c|}{ WE } \\
\hline & Mean & St.Dv. & Mean & St.Dv. & Mean & St.Dv. & Mean & St.Dv. \\
\hline \multicolumn{9}{|l|}{ Demographics } \\
\hline Age & 44.62 & (.393) & 39.52 & $(.124)$ & 42.48 & $(.581)$ & 39.50 & $(.124)$ \\
\hline Unskilled & 0.157 & $(.016)$ & 0.182 & $(.005)$ & 0.165 & $(.023)$ & 0.181 & $(.005)$ \\
\hline Skilled & 0.519 & $(.022)$ & 0.466 & $(.006)$ & 0.502 & $(.029)$ & 0.427 & $(.006)$ \\
\hline Married & 0.886 & $(.014)$ & 0.783 & $(.005)$ & 0.886 & $(.019)$ & 0.790 & $(.005)$ \\
\hline Children 0-2 & 0.132 & $(.015)$ & 0.126 & $(.004)$ & 0.075 & $(.016)$ & 0.111 & $(.004)$ \\
\hline Children 3-6 & 0.183 & $(.017)$ & 0.173 & $(.005)$ & 0.161 & $(.023)$ & 0.175 & $(.005)$ \\
\hline Children 7-16 & 0.369 & $(.021)$ & 0.299 & $(.005)$ & 0.282 & $(.028)$ & 0.336 & $(.006)$ \\
\hline Hhold. size & 3.15 & $(.053)$ & 2.849 & $(.015)$ & 2.776 & $(.070)$ & 2.89 & $(0.015)$ \\
\hline Citizenship & 0.968 & $(.174)$ & 0.973 & $(.279)$ & 0.941 & $(.236)$ & 0.985 & $(.166)$ \\
\hline Health & 1.632 & $(.769)$ & 1.546 & $(.716)$ & 1.655 & $(.869)$ & 1.570 & $(.745)$ \\
\hline $\mathrm{N}^{\circ}$ of $\mathrm{SE}$ in hhold. & 0.132 & $(.015)$ & 0.027 & $(.002)$ & 0.322 & $(.029)$ & 0.062 & $(.003)$ \\
\hline \multicolumn{9}{|l|}{ Labor market } \\
\hline Working hours & 53.07 & (.633) & 40.43 & $(.120)$ & 41.45 & (1.197) & 34.44 & $(.111)$ \\
\hline if no small child. & 53.18 & $(.694)$ & 40.49 & $(.131)$ & 41.57 & $(1.271)$ & 34.40 & $(.120)$ \\
\hline if small child. & 52.33 & $(1.469)$ & 39.98 & $(.274)$ & 39.84 & $(3.052)$ & 34.79 & $(.277)$ \\
\hline Previous unempl. & 0.312 & $(.021)$ & 0.346 & $(.006)$ & .345 & $(.030)$ & 0.361 & $(.006)$ \\
\hline \multicolumn{9}{|l|}{ Income (in euros) } \\
\hline Income from work & 22,436 & (1319) & 15,640 & $(92)$ & 9,716 & $(664)$ & 11,355 & $(68)$ \\
\hline Capital income & 835 & (183) & 185 & (19) & 141 & (31) & 90 & (7) \\
\hline Household income & 37,132 & $(1480)$ & 28,567 & (143) & 35,997 & $(2173)$ & 28,436 & $(150)$ \\
\hline \multicolumn{9}{|l|}{ Sector } \\
\hline Manufacturing & 0.132 & $(.015)$ & 0.268 & $(.005)$ & 0.125 & $(.021)$ & 0.115 & $(.004)$ \\
\hline Constr./Wholesale & 0.450 & $(.022)$ & 0.219 & $(.005)$ & 0.282 & $(.028)$ & 0.109 & $(.004)$ \\
\hline Transport \& Hotel & 0.098 & $(.013)$ & 0.102 & $(.004)$ & 0.098 & $(.019)$ & 0.057 & $(.003)$ \\
\hline Financial & 0.134 & $(.015)$ & 0.119 & $(.004)$ & 0.043 & $(.013)$ & 0.101 & $(.004)$ \\
\hline Services & 0.187 & $(.017)$ & 0.293 & $(.005)$ & 0.451 & $(.031)$ & 0.618 & $(.006)$ \\
\hline No Observations & 509 & & 6,940 & & 255 & & 6,840 & \\
\hline
\end{tabular}

to participate in the labor market, we focus on self-employment versus wage employment. We consider transitions from wage employment (WE) and non-employment $(N E)$ (unemployment or out of labor force) to self-employment, the alternative being wage employment. Our dependent variable takes the value 1 if the individual who was a wageworker or a non-employed in period $t-1$ becomes self-employed in period $t$, and 0 if the individual continues or becomes a wage-worker in period $t$. Thus, the results refer to the probability of choosing self-employment, compared to choose wage employment.

We estimate binary logit models for each country and for men and women separately, conditioning on the labor market status before the entry (employment or nonemployment) ${ }^{19}$ and by a set of observed personal characteristics and economic variables. With respect to the latter, we consider that when people make their transition decision, they use prior economic indicators in assessing their choice. Therefore, we use macroeconomic variables that are averages of the values over the previous year. We use information about the individual's characteristics a period earlier (i.e. before switching), otherwise possible consequences of transition are likely to be confused with the causes of it.

Table 6 shows the number of observations per transition from wage employment and non-employment. One of the most prominent feature for Denmark is the relatively 
Table 4 Descriptive statistics for the Spanish sample

\begin{tabular}{|c|c|c|c|c|c|c|c|c|}
\hline & \multicolumn{4}{|c|}{ Men } & \multicolumn{4}{|c|}{ Women } \\
\hline & \multicolumn{2}{|c|}{ SE } & \multicolumn{2}{|c|}{ WE } & \multicolumn{2}{|c|}{ SE } & \multicolumn{2}{|c|}{ WE } \\
\hline & Mean & St.Dv. & Mean & St.Dv. & Mean & St.Dv. & Mean & St.Dv. \\
\hline \multicolumn{9}{|l|}{ Demographics } \\
\hline Age & 40.69 & $(.160)$ & 37.55 & $(.082)$ & 39.68 & $(.257)$ & 35.59 & (.099) \\
\hline Unskilled & 0.605 & $(.008)$ & 0.525 & $(.004)$ & 0.550 & $(.013)$ & 0.400 & $(.005)$ \\
\hline Skilled & 0.201 & $(.006)$ & 0.208 & $(.003)$ & 0.203 & $(.010)$ & 0.229 & $(.004)$ \\
\hline Married & 0.798 & $(.006)$ & 0.704 & $(.004)$ & 0.701 & $(.012)$ & 0.584 & $(.005)$ \\
\hline Children 0-2 & 0.095 & $(.005)$ & 0.107 & $(.002)$ & 0.077 & $(.007)$ & 0.077 & $(.003)$ \\
\hline Children 3-6 & 0.161 & $(.006)$ & 0.157 & $(.003)$ & 0.140 & $(.009)$ & 0.119 & $(.003)$ \\
\hline Children 7-16 & 0.414 & $(.008)$ & 0.365 & $(.004)$ & 0.337 & $(.012)$ & 0.326 & $(.005)$ \\
\hline Hhold. size & 3.965 & $(.023)$ & 3.835 & $(.010)$ & 3.679 & $(.039)$ & 3.609 & $(.014)$ \\
\hline Citizenship & 0.989 & $(.001)$ & 0.990 & $(.003)$ & 0.989 & $(.002)$ & 0.990 & $(.001)$ \\
\hline $\mathrm{N}^{\circ}$ of SE in hhold. & 0.232 & $(.008)$ & 0.095 & $(.003)$ & 0.407 & $(.015)$ & 0.149 & $(.004)$ \\
\hline Health & 2.043 & $(.011)$ & 1.960 & $(.005)$ & 2.058 & $(.019)$ & 1.964 & $(.007)$ \\
\hline \multicolumn{9}{|l|}{ Labor market } \\
\hline Working hours & 51.508 & $(.251)$ & 42.737 & $(.075)$ & 44.347 & $(.467)$ & 35.580 & $(.119)$ \\
\hline if no small child. & 51.429 & $(.263)$ & 42.642 & $(.079)$ & 44.711 & $(.484)$ & 35.619 & $(.125)$ \\
\hline if small child. & 52.256 & $(.858)$ & 43.533 & $(.225)$ & 40.00 & $(1.721)$ & 35.118 & $(.384)$ \\
\hline Previous unempl. & 0.367 & $(.007)$ & 0.457 & $(.004)$ & 0.402 & $(.012)$ & 0.539 & $(.005)$ \\
\hline \multicolumn{9}{|l|}{ Income (in euros) } \\
\hline Income from Work & 11,730 & (199) & 13,775 & (76.98) & 5,932 & $(237)$ & 9,743 & (78) \\
\hline Capital income & 314 & $(23)$ & 216 & (9) & 87 & $(12)$ & 93 & (6) \\
\hline Household income & 21,955 & $(273)$ & 24,240 & $(114.3)$ & 22,485 & $(481)$ & 26,368 & $(160)$ \\
\hline \multicolumn{9}{|l|}{ Sector } \\
\hline Manufacturing & 0.141 & $(.005)$ & 0.292 & $(.004)$ & 0.080 & $(.007)$ & 0.135 & $(.003)$ \\
\hline Const./Wholesale & 0.471 & $(.008)$ & 0.276 & $(.004)$ & 0.421 & $(.013)$ & 0.152 & $(.004)$ \\
\hline Transport \& Hotel & 0.205 & $(.006)$ & 0.127 & $(.003)$ & 0.140 & $(.009)$ & 0.093 & $(.003)$ \\
\hline Financial & 0.114 & $(.005)$ & 0.085 & $(.002)$ & 0.111 & $(.008)$ & 0.116 & $(.003)$ \\
\hline Services & 0.067 & $(.004)$ & 0.217 & $(.003)$ & 0.247 & $(.010)$ & 0.502 & $(.005)$ \\
\hline $\mathrm{N}^{\circ}$ Observations & 4,047 & & 16,129 & & 1,492 & & 9,653 & \\
\hline
\end{tabular}

low number of transitions into self-employment: $1.55 \%$ of males and $0.97 \%$ of females become self-employed, compared to $4.99 \%$ and $4.96 \%$ of Spanish males and females, respectively. ${ }^{20}$ If one specifically looks at the transition rate from non-employment, it is around $4 \%$ for Denmark (3.7\% for males and $4.3 \%$ for females) whereas the similar transition rate in Spain is much larger (for males $17 \%$ and for females $16.9 \%$ ).

Table $7^{21}$ presents the estimation results. The qualitative impact of the variables is discussed in terms of the sign and statistical significance of the estimated coefficients. We also report in Table 8 the predicted probabilities for some individual types.

We begin by considering the effect of work income for wage-workers. We find that Spanish men and women and also Danish women in the bottom part of the wage distribution are more likely to leave employment and start as self-employed. This finding

Table 5 Labor market status by chances of finding a job within the next year

\begin{tabular}{|c|c|c|c|c|c|c|c|c|}
\hline & \multicolumn{4}{|c|}{ Denmark } & \multicolumn{4}{|c|}{ Spain } \\
\hline & \multicolumn{2}{|c|}{ Men } & \multicolumn{2}{|c|}{ Women } & \multicolumn{2}{|c|}{ Men } & \multicolumn{2}{|c|}{ Women } \\
\hline & WE & SE & WE & SE & WE & SE & WE & SE \\
\hline Bad or very bad & $13 \%$ & $7 \%$ & $21 \%$ & $20 \%$ & $59 \%$ & $72 \%$ & $67 \%$ & $85 \%$ \\
\hline
\end{tabular}


Table 6 Number of observations per transition

\begin{tabular}{|c|c|c|c|c|c|c|c|c|}
\hline \multirow[b]{4}{*}{ Source State } & \multicolumn{8}{|c|}{ Destination state } \\
\hline & \multicolumn{4}{|c|}{ Denmark } & \multicolumn{4}{|c|}{ Spain } \\
\hline & \multicolumn{2}{|c|}{ Men } & \multicolumn{2}{|c|}{ Women } & \multicolumn{2}{|c|}{ Men } & \multicolumn{2}{|c|}{ Women } \\
\hline & WE & SE & WE & SE & WE & SE & WE & SE \\
\hline WE & 5,687 & 78 & 5,218 & 24 & 10,608 & 284 & 5,645 & 84 \\
\hline $\mathrm{NE}$ & 483 & 19 & 782 & 35 & 1,781 & 366 & 1,947 & 396 \\
\hline
\end{tabular}

is consistent with the view that disadvantaged -e.g. low wage-workers- tend to become self-employed and suggests that this group benefits more from being self-employed than better paid workers. For Danish males the opposite is true: the probability of switching for a Danish male previously employed with the average income is 2.77 , while this figure rises to 4.43 if the individual has high labor income (see Table 8). Regarding the effect of unemployment benefits receipt, we find that it considerable reduces the probability of entering self-employment instead of wage-employment for Spanish unemployed,

Table 7 Probability of entering into self-employment

\begin{tabular}{|c|c|c|c|c|}
\hline \multirow[b]{2}{*}{ Variable } & \multicolumn{2}{|c|}{ Denmark } & \multicolumn{2}{|c|}{ Spain } \\
\hline & Women & Men & Women & Men \\
\hline Constant & $-5.952(-1.49)$ & $-9.523(-3.15)$ & $-8.537(-3.46)$ & $-10.339(-5.89)$ \\
\hline Age & $0.120(0.74)$ & $0.281(2.15)$ & $0.299(3.77)$ & $0.364(5.18)$ \\
\hline $\mathrm{Age}^{2}$ & $-0.0006(-0.34)$ & $-0.003(-1.87)$ & $-0.003(-3.63)$ & $-0.004(-5.13)$ \\
\hline Married & $0.565(1.18)$ & $-0.119(-0.71)$ & $-0.054(-0.36)$ & $0.431(3.25)$ \\
\hline Citizenship & $-1.632(-2.97)$ & $-0.444(-0.80)$ & $-0.460(-0.89)$ & $-0.774(-1.89)$ \\
\hline Health & $0.077(0.42)$ & $-0.019(-0.13)$ & $0.058(0.72)$ & $0.087(1.43)$ \\
\hline Univ. educ. & $2.384(1.57)$ & $0.963(1.08)$ & $1.332(2.56)$ & $1.441(4.65)$ \\
\hline Skilled & $0.189(0.46)$ & $0.667(1.77)$ & $-0.101(-0.58)$ & $0.322(2.90)$ \\
\hline Relative se & $1.938(6.03)$ & $0.776(1.73)$ & $0.948(8.82)$ & $0.860(9.35)$ \\
\hline Child 0-2 & $1.214(2.33)$ & $0.583(1.76)$ & $-0.787(-1.31)$ & $0.032(0.18)$ \\
\hline Child $0-2 \times N E$ & $-0.622(-0.90)$ & $0.025(0.00)$ & $1.385(2.14)$ & $0.254(0.91)$ \\
\hline Child 3-6 & $0.486(1.27)$ & $-0.087(-0.29)$ & $-0.028(-0.15)$ & $-0.194(-1.48)$ \\
\hline Child 7-16 & $-0.436(-1.13)$ & $-0.027(-0.11)$ & $-0.071(-0.54)$ & $-0.188(-1.88)$ \\
\hline Wholesale $\times$ WE & $0.333(0.84)$ & $0.142(0.52)$ & $0.464(2.67)$ & $0.546(4.73)$ \\
\hline Hotel/Trans. $\times$ WE & $0.217(0.33)$ & $-0.298(-0.68)$ & $-0.015(-0.07)$ & $0.363(2.49)$ \\
\hline Finance $\times$ WE & $-0.516(-0.78)$ & $0.076(0.23)$ & $-0.244(-1.15)$ & $0.573(3.46)$ \\
\hline Services $\times$ WE & $-0.622(-1.67)$ & $-1.0676(-2.43)$ & $-0.772(-4.45)$ & $-0.369(-1.99)$ \\
\hline Work income $\times$ WE & $-0.0001(-3.23)$ & $0.00003(3.26)$ & $-0.00007(-4.45)$ & $-0.00005(-6.66)$ \\
\hline Capital income & $0.0002(0.83)$ & $0.00005(2.61)$ & $-0.0001(-0.70)$ & $0.00002(0.60)$ \\
\hline Benefits $\times N E$ & $-0.301(-0.67)$ & $0.547(0.93)$ & $-1.141(-3.91)$ & $-0.966(-5.84)$ \\
\hline Job tenure $\times W E$ & $-0.131(-1.94)$ & $-0.083(-2.08)$ & $-0.134(-3.75)$ & $-0.131(-6.26)$ \\
\hline Private sector $\times$ WE & $1.782(3.32)$ & $0.930(2.13)$ & $0.597(1.92)$ & $0.822(3.44)$ \\
\hline Working hours $\times$ WE & $-0.189(-4.02)$ & $-0.127(-3.98)$ & $-0.092(-2.96)$ & $-0.077(-3.30)$ \\
\hline Working hours ${ }^{2} \times$ WE & $0.002(3.91)$ & $0.002(4.85)$ & $0.001(3.00)$ & $0.001(4.73)$ \\
\hline U. Rate & $8.463(0.66)$ & $-6.511(-0.60)$ & $1.325(0.53)$ & $4.258(2.83)$ \\
\hline U. Ratex Univ.educ. & $-25.157(-1.28)$ & $-3.223(-0.20)$ & $-3.015(-1.76)$ & $-6.622(-4.03)$ \\
\hline NE & $-0.813(-1.51)$ & $0.156(0.18)$ & $0.267(0.57)$ & $1.097(2.19)$ \\
\hline $\mathrm{N}^{\circ}$ Observations & 6,042 & 6,248 & 7,833 & 12,756 \\
\hline Log-likelihood & -234.421 & -431.498 & -1146.483 & -2084.476 \\
\hline
\end{tabular}

Logit estimates.

Note: t-statistics in brackets. 
Table 8 Predicted probabilities of entering into self-employment

\begin{tabular}{|c|c|c|c|c|}
\hline & \multicolumn{2}{|c|}{ Denmark } & \multicolumn{2}{|c|}{ Spain } \\
\hline & Women & Men & Women & Men \\
\hline Standard' (from WE) & 3.29 & 2.77 & 1.33 & 5.94 \\
\hline Without small children (from WE) & 1.00 & 1.57 & 2.88 & 5.76 \\
\hline Low earnings ${ }^{2}$ (from WE) & 6.56 & 2.19 & 2.06 & 9.06 \\
\hline High earnings (from WE) & 0.70 & 4.43 & 0.50 & 2.48 \\
\hline Unskilled (from WE) & 2.41 & 1.44 & 4.02 & 9.07 \\
\hline Standard ${ }^{1}$ (from NE) & 18.66 & 6.04 & 35.81 & 44.37 \\
\hline Without small children (from NE) & 7.24 & 6.44 & 23.89 & 42.10 \\
\hline With U. Benefits (from NE) & 16.39 & 10.79 & 4.39 & 22.23 \\
\hline
\end{tabular}

Notes: 1 . Standard: age 40, married, spouse non self-employed, with children 0-2, skilled, Danish/Spanish citizen, without univ. education, health index $=2$, working hours 40 , private sector, whole sale, job tenure 2 years and average wage and capital income. For non-employed probabilities, individual not receiving benefits. Unemployment rate $10 \%$. 2. Low and high earnings are earnings half and double the average ones respectively.

while for the Danish the effect is not significant. Table 8 shows that receiving benefits decreases the probability of switching into self-employment instead of switching into wage-employment by more than 30 and 20 percentage points (p.p) for Spanish females and males, respectively. This result is again in agreement with the disadvantage theory for the Spanish workers, since it seems that for the unemployed it is progressively harder to find a wage job and when benefits exhaust the probability of switching into self-employment increases.

Regarding the previous labor market status, we see that Spanish males and Spanish females with small children coming from non-employment are more likely to enter self-employment than salary workers, while for Danish males and females there are not significant differences between non-employed and wage employed. However, one should bear in mind that we observe few transitions from non-employment to self-employment in the Danish data, making the Danish results less robust.

As to the effect of children, we find that having small children has a positive impact on the choice of self-employment versus wage-employment for Spanish women coming from non-employment, and negative for previously employed women. For Danish women we find the opposite although non-significant effect. In terms of the estimated probabilities, the probability of entering into self-employment from non-employment for a Spanish women with small children is about 12 p.p larger than for women without small children. These results are consistent with the fact that marginalized groups in the labor market, in this case non-employed mothers with small children, are more likely to enter self-employment in Spain, while in Denmark this does not seem to be the case. For women coming from wage-employment we find that the effect of small children is positive for Danish and negative, although non-significant, for Spanish women. In terms of the estimated probabilities we find that having small children increases the probability of switching from wage-employment by approximately 2.5 p.p. for Danish women and decreases about 1 p.p. for Spanish ones. Therefore, our results do not seem to support the hypothesis that self-employment is used as a work arrangement to better balance family and work for those women who already have a wage-employment.

When examining the effect of the attachment to the wage-employment, measured as tenure in employment, we find strong negative impact on the entrance into self- 
employment. This result is found for all four groups but most pronounced for Spanish workers.

Finally, the results indicate that having a relative in the self-employed sector increases the probability of entering self-employment in all cases. This result goes in favor of the hypothesis about transfers of human capital. For Spanish individuals we obtain a nonsignificant effect of assets on the probability of entrance, while for Danish workers we find that assets have a positive and significant impact on the probability of entering upon self-employment. As mentioned in the theoretical section, this could be interpreted as either evidence that this group is more often liquidity constrained or that they are more risk averse.

\section{Concluding remarks}

In this paper we find that self-employment seems to hold attraction for different groups of workers in Denmark and Spain. The most striking difference between the two countries is that in Spain self-employment seems to offer individuals that can be considered as disadvantaged in the labor market a beneficial alternative to wage employment, while this pattern is not so clear in Denmark. Specifically, in Spain individuals in the bottom part of the wage distribution start more often their own business than in Denmark. Moreover, the entrance form non-employment is considerably higher for Spanish than for Danish workers, specially if they do not receive unemployment benefits. Another significant difference is that non-employed Spanish mothers with small children seem to choose to work as self-employed instead than as a wage-worker more often than Danish women. This contributes to the picture that in Spain more marginalized groups use selfemployment, while the picture for Denmark is more blur. Finally, we do not find strong evidence that the lack of relatively cheap child care in Spain put some extra incentives on mothers with small children to start as self-employed, since we only find evidence in favor of this hypothesis for women coming from non-employment but not for those coming from wage-employment.

Given this evidence, we tentatively come to the conclusion that several aspects of the labor market environment could partly explain the different characteristics of the selfemployed workers in both countries. Firstly, in Spain the social security system is not as generous as in Denmark. This means that groups at risk for being marginalized in the labor market are to a larger extent forced to search for alternative employment, such as self-employment. Secondly, the high unemployment rate in Spain has made it even more difficult to enter the wage employment sector, which also can explain the high probability for individuals not working to entering upon self-employment in Spain. Thirdly, the significant difference in the gender pattern between Spain and Denmark may be related to the female labor force participation. Denmark has a long tradition for a high female labor force participation, while Spain has had a much lower female labor force participation. This means that Danish women are more integrated in the labor market, and therefore might find it easier to enter the wage employment compared to Spanish women.

We are aware of the fact that some other aspects of the two labor markets, such as different rates of unionization or firms' size, may also be potentially important in explaining part of the differences in self-employment rates and complement our explanation. Notwithstanding, our results could have interesting implications from a policy point of view, since policies aimed at fostering self-employment are viewed as an instrument 
to reduce unemployment and to reinforce the economic growth. The fact that selfemployment provides an outlet for relatively disadvantaged workers in Spain compared to Denmark, in particular for low wage workers, unemployed without benefits, and nonemployed mothers with small children, suggests that probably the institutional setting in Spain has a negative impact on entrepreneurial activities of high value added. In this respect, the effort from a policy point of view should be directed towards improving the conditions to start and operate a business.

\section{Endnotes}

${ }^{1}$ The increase in the number of females choosing to work for themselves represents one of the most striking recent trends in many OECD countries. For instance, Devine (1994) shows that in the U.S. the self-employment rate among women increased from 4.1 percent in 1975 to 6.7 percent in 1990.

${ }^{2}$ Some studies on self-employment in Denmark and Spain are Plougmann and Buhl (1998) who consider the role of institutions and Blume et al. (2003), who focus on selfemployment and immigration for Denmark. For Spain, Carrasco (1999) focuses on male transitions to self-employment and on self-employment duration, and Bonet et al. (2012) study the role of self-employment to balance work and family.

${ }^{3}$ Some studies that include women in their estimates of the determinants of selfemployment are McPherson (1988), Boden (1999) and Dunn and Holtz-Eakin (1996), Williams (2000), and Cowling and Taylor (2001).

${ }^{4}$ This is in contrast to Blanchflower (2000), who analyses the stock rather than the entrance to self-employment.

${ }^{5}$ We include the economically inactive since excluding them may introduce selection bias, especially for women.

${ }^{6}$ Some exceptions are Blau (1987), Long (1982), and Schuetze (2000).

${ }^{7}$ Carrasco (1999) finds for Spain that receiving unemployment benefits reduces the probability of entering into self-employment.

${ }^{8}$ Other strand of the literature looks at how labor market institutions affects fertility. Adsera $(2004,2005)$ finds that on a country level the fertility and fraction of self-employed are negatively correlated while fertility and the duration of maternity leave are positively correlated. This indicates that institutions are likely to affect both the choice of occupation and the fertility decision. Nonetheless, in this study we condition on fertility and analyze how the presence of young children affects the transition into self-employment, and not how institutions affect fertility decisions.

${ }^{9}$ See Andersen and Svarerz (2007) for details.

${ }^{10}$ See Bentolila et al. (2006) for details.

${ }^{11}$ See Andersen and Svarerz (2007) for details.

${ }^{12}$ Specifically, in 1996 it was reduced from 84 to 60 months. In 1998 the duration was further reduced from 60 months to 48 months.

${ }^{13}$ For a detailed description of the Spanish unemployment insurance system see Bentolila and Jimeno (2006).

${ }^{14}$ See Pylkkänen and Smith (2002) for details.

${ }^{15}$ See Nollenberger and Rodríguez-Planas (2011) for details.

${ }^{16}$ The labor for participation in 1995 was $73.6 \%$ for women and $85.0 \%$ for men.

${ }^{17}$ The labor force participation in 1995 was $45.1 \%$ for women and $73.6 \%$ for men. 
${ }^{18}$ According to the Spanish Statistical Institute and the Statistiske efterretninger, the percentage of the labor force working part time is about $10 \%$ for Danish males and $20 \%$ for Danish females, while for Spain these figures are around 2\% and 12\% respectively for the years under study.

${ }^{19}$ We would rather focus on transitions for employees and non-employees individuals separately. However, due to the small sample size in some cases, we have just conditioned on previous state and interacted it with some of the explanatory variables. For the same reason, our estimates do not control for time invariant unobserved heterogeneity between individuals.

${ }^{20}$ Notice that the small sample size for certain type of transitions could affect the precision of the estimates. We have performed a similar analysis using a larger data set $(0.5 \%$ of register data for Denmark and the Continuous Family Expenditure Survey for Spain) and the results are very similar to those found with the ECHP.

${ }^{21}$ The number of observations does not exactly coincide with the transitions shown in Table 6 because of some missing observations for some explanatory variables.

Competing interests

The IZA Journal of Labor Policy is committed to the IZA Guiding Principles of Research Integrity. Both authors declare that they observed these principles.

\begin{abstract}
Acknowledgements
We are grateful to Manuel Arellano, J. Carlos Berganza, Olympia Bover, Martin Browning, J. Ignacio Garcia-Perez, and Maite Martinez-Granado for helpful comments on this work. We have also benefitted from the comments of two anonymous referees and seminar participants at Aarhus School of Business, University of Copenhagen, Universidad de Oviedo and Universidad Carlos III de Madrid. Research funding from the Spanish Ministry of Education, Grant No. ECO2011-12936-E and the Danish Research Agency (Freja Grants) is acknowledged.
\end{abstract}

Responsible editor: Juan Francisco Jimeno.

Received: 27 September 2012 Accepted: 18 December 2012

Published: 27 December 2012

\title{
References
}

Andersen TM, Svarerz M (2007) Flexicurity-labour market performance in Denmark. CESifo Econ Studies 53(3): 389-429 Adsera A (2004) Changing fertility rates in developed countries. The impact of labor market institutions. J Popul Econ 17(1): 17-43

Adsera, A (2005) Where are the babies? Labor market conditions and fertility in Europe. Eur J Popul 17(1): 1-32 Bentolila S, Jimeno JF (2006) Spanish unemployment: the end of the wild ride? In: M. Werding (ed) Structural unemployment in Western Europe: reasons and remedies. Cambridge MIT Press, London

Blau DM (1987) A time-series analysis of self-employment in the United State. J Pol Econ 95(3): 445-67

Blanchflower D (2000) Self-employment in OECD countries. Labour Econ 7(5): 471-505

Blanchflower D, Oswald A (1998) What makes an entrepreneur. J Labor Eco 16(1): 26-60

Blume K, Nielsen HS, Ejrnæs M, Würtz (2003) Self-employment among immigrants: a last resort? J Popul Eco 22(4): 881-908

Boden RJ (1996) Gender and self-employment selection: an empirical assessment. J Socio Econ 25(6): 671-682

Boden, RJ (1999) Flexible working hours, family responsibilities, and female self-employment: gender differences in self-employment selection. Am J Econ Sociol 58(1): 71-83

Bonet R, Cruz C, Fernandez-Kranz D, Justo R (2012) Temporary contracts and work-family balance in a dual labor market. Ind Labor Relat Rev forthcoming

Carrasco R (1999) Transition to and from Self-employment in Spain: an empirical analysis. Oxf Bull Econ Stat 61 (3): 315-341

Clark K, Drinkwater S (2000) Pushed out or pulled in? Self-employment among ethnic minorities in England and Wales. Labour Econ 7: 603-628

Connelly R (1992) Self-employment and providing child care. Demography 29(1): 17-29

Conway P, Janod V, Nicoletti G (2005) Product market regulation in OECD countries: 1998 to 2003. OECD ECO/WKP n 419

Cowling M, Taylor M (2001) Entrepreneurial women and men: two different species? Small Bus Econ 16: 167-175

Devine T (1994) Changes in wage-and-salary returns to skill and the recent rise in female self-employment. Am Econ Rev 84(2): 108-113

Dunn TA, Holtz-Eakin DJ (2000) Financial capital, human capital, and the transition to self-employment: evidence from intergenerational links. J Labour Econ 18(2): 282-305

Evans DS, Jovanovic B (1989) An estimated model of entrepreneurial choice under liquidity constraints. J Pol Econ 97(4): 808-827

Evans DS, Leighton L (1989) Some aspects of entrepreneurship. Am Econ Rev 79(3): 519-535 
Hughes K (2003) Pushed or pulled? Women's entry into self-employment and small business ownership. Gender, Work Organ 10(4): 433-454

Light I (1980) Disadvantaged minorities in self-employment. Int J Comp Sociol 20: 31-45

Lombard KV (2001) Female self-employment and demand for flexible, nonstandard work schedules. Econ Inq 39(2): 214-237

Long JE (1982) The income tax and self-employment. Natl Tax J 35(1): 31-42

Moore C, Mueller R (2002) The transition from paid to self-employment in Canada: the importance of push factors.

Appl Econ 34: 791-801

McPherson DA (1988) Self-employment and married women. Econ Lett 28: 281-284

Nollenberger N, Rodríguez-Planas N (2011) Child care, maternal employment and persistence: a natural experiment from Spain. IZA Discuss Paper n 5888

OECD (1992) Recent developments in self-employment. OECD Employment Outlook, July

OECD (2011) Product market regulation database

Plougmann P, Buhl S (1998) Self-employment in Denmark -trends and policy manuscript

Pylkkänen E, Smith N (2002) Career interruptions due to parental leave a comparative study of Denmark and Sweden.

Economic Studies, Department of Economics, Goteborg University, 120

Schuetze HJ (2000) Taxes, economic conditions and recent trends in self-employment: a Canada-U.S. comparison. Labor Econ 7(5): 507-554

Taylor MP (1999) Survival of the fittest? An analysis of self-employment duration in Britain. Econ J 109(March): 141-155

Wellington AJ (2006) Self-employment: the new solution for balancing family and career? Labour Econ 13: 357-386

Williams DR (2000) Consequences of self-employment for women and men in the U.S. Labour Econ 7(5): 665-687

World Bank (2012) Doing Business

doi:10.1186/2193-9004-1-13

Cite this article as: Carrasco and Ejrnæs: Labor market conditions and self-employment: a Denmark-Spain comparison. IZA Journal of Labor Policy 2012 1:13.

\section{Submit your manuscript to a SpringerOpen ${ }^{\circ}$ journal and benefit from:}

- Convenient online submission

- Rigorous peer review

- Immediate publication on acceptance

- Open access: articles freely available online

- High visibility within the field

- Retaining the copyright to your article

Submit your next manuscript at $\boldsymbol{\triangleright}$ springeropen.com 